
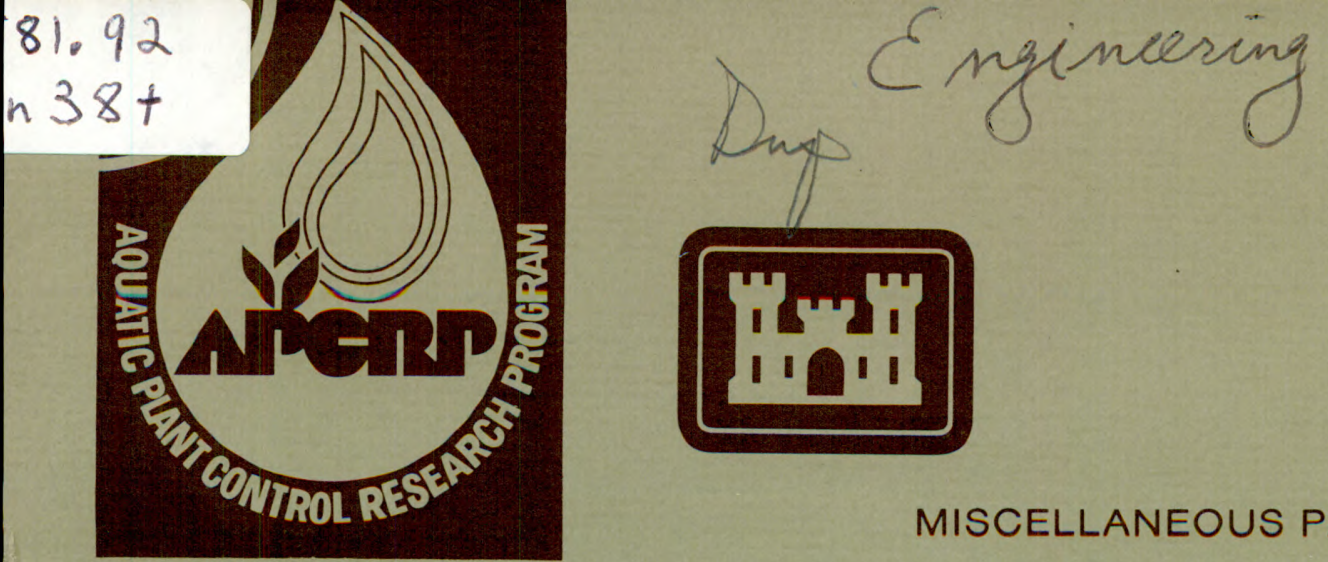

MISCELLANEOUS PAPER A-82-1

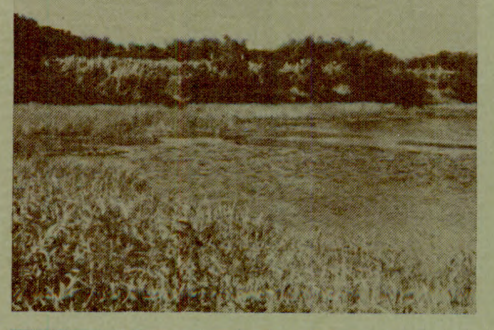

\title{
ORGANISMS IMPACTING WATERHYACINTH IN THE PANAMA CANAL
}

By Dana R. Sanders, Sr., Russell F. Theriot, Edwin A. Theriot

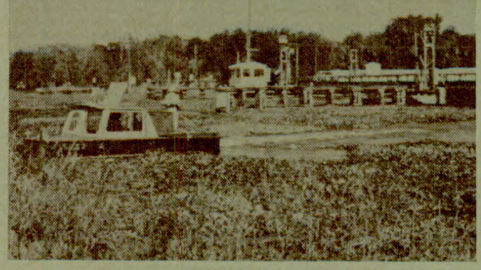

Environmental Laboratory

U. S. Army Engineer Waterways Experiment Station

P. O. Box 631, Vicksburg, Miss. 39180

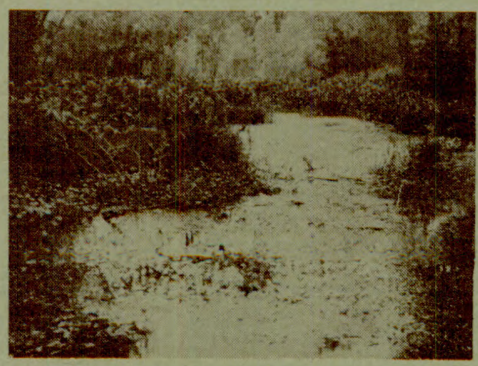

February 1982

Final Report

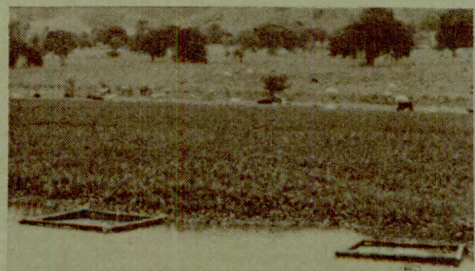

THE LIBRARY OE THE
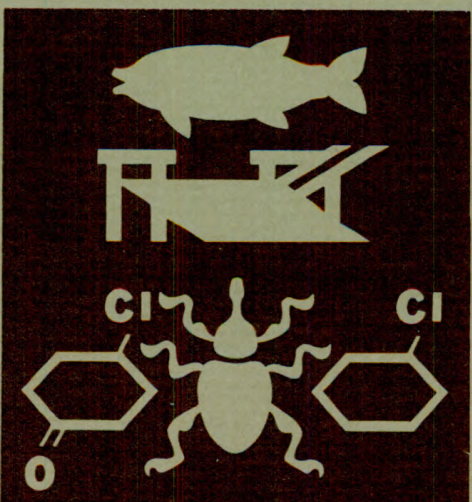

and

Approved For Public Release; Distribution Unlimited

\section{MAY $18: 982$}

UNIVERSITY OF ILLINOIS AT URBANA-CHAMPAION

Prepared for Panama Canal Commission

Balboa Heights, Republic of Panama

Office, Chief of Engineers, U. S. Army

Washington, D. C. 20314

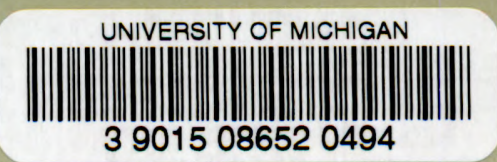

